\title{
Ethanol extract of soursop leaf inhibits acid production and adhesion of Streptococcus mutans
}

\author{
Friska Ani Rahman ${ }^{1 *}$, Rahsunji Intan ${ }^{1}$ \\ ${ }^{1}$ Dental Hygiene Study Program, Faculty of Dentistry Gadjah Mada University, Indonesia
}

\begin{abstract}
Introduction: Dental caries and dental plaque are the most popular global oral health problems. The primary step of dental caries is characterized by damage of tooth surfaces affected by acids which are by-products of sugar metabolism by a cariogenic bacteria. One of the cariogenic bacteria is Streptococcus mutans. Annona muricata is traditionally applied as an herbal remedy for various illnesses and has been recognized in a previous study as an antimicrobial agent. This study was aimed to determine inhibition of ethanol extract of soursop on acid production and adhesion of Streptococcus mutans. Methods: Soursop leaf extracted by maceration using $70 \%$ ethanol solvent. The extracts obtained were tested at various concentrations. To examine the effect of ethanol extract of Soursop on acid production by S. mutans, the $\mathrm{pH}$ of the culture was determined using a $\mathrm{pH}$ meter. Inhibition of adhesion of $\mathrm{S}$. mutans to the salivacoated hydroxyapatite (S-HA) discs was quantified using colony counting on TYS2OB agar plates. Results: Ethanol extract of soursop showed significant inhibition of acid production at the concentrations of $50,75,100,125$ and $150 \mathrm{mg} / \mathrm{ml}$ compared to the negative control group. The $\mathrm{pH}$ of $\mathrm{S}$. mutans cultures in the presence of ethanol extract of Soursop leaf at various concentrations was higher than negative control, but there were no differences in $\mathrm{pH}$ value between the various concentrations of ethanol extract of Soursop leaf. The extract clearly inhibited S. mutans adhesion to saliva coated hydroxyapatite beads at the concentration $50,75,100,125$ and $150 \mathrm{mg} / \mathrm{ml}$ compared to the negative control group. Adhesion decreased with increasing concentrations of ethanol extract of Soursop leaf, but there was not significant difference in colony count between the various concentrations of ethanol extract of Soursop leaf. Conclusions: The ethanol extract of Annona muricata leaf can inhibit acid production and adhesion of S. mutans.
\end{abstract}

Keywords: soursop; Annona muricata; Streptococcus mutans; acid production; adhesion

p-ISSN: 1979-0201; e-ISSN: 2549-6212; Available from: http://jurnal.unpad.ac.id/pjd/article/view/29385

DOI: 10.24198/pid.vol33no3.29385

Submission: Sep 08, 2020; Accepted: Oct 30, 2021; Published online: Nov 30, 2021

Corresponding author: Friska Ani Rahman, Dental Hygiene Study Program, Faculty of Dentistry Gadjah Mada University, Indonesia. 1, Jalan Denta, Sleman, Special Region of Yogyakarta, 55281, Indonesia. Phone: +62815-7855-7944; Email: friska ani@ugm.ac.id 


\section{INTRODUCTION}

Based on the Indonesia Basic Health Research (Riskesdas) in 2013, dental caries is the most common oral cavity infection in Indonesia. ${ }^{1}$ The virulent properties of cariogenic bacteria in the oral cavity cannot be separated from the occurrence of caries. One of the cariogenic bacteria that plays an important role in plaque formation and dental caries is Streptococcus mutans (S. mutans). ${ }^{2}$ Pathogenesis of dental caries requires numerous steps, such as attachment of bacteria to the pellicle on the superficial tooth structures caused by acids which produced during dietary sugars metabolism by bacteria. ${ }^{3}$

Streptococcus mutans metabolize carbohydrates and produce by-product in the form of organic acids. Accumulation of metabolic acids induces demineralization of the tooth surface, in which can develop into dental caries. ${ }^{4}$ Plant-based therapy is growing in developed and developing countries because of the increasing recognition that they are natural products. Secondary metabolites produced by plants can be used as antimicrobials. $^{5}$

Many studies have revealed that natural remedies can interfere with virulence factors of S. mutans. ${ }^{6,7,8,9}$ Annona muricata leaves are traditionally used to treat headaches, fever, toothache, cough, and asthma. ${ }^{10}$ Annona muricata leaf has proven to be able to inhibits the growth of S. mutans in previous studies. ${ }^{11,12,13,14}$ This study was aimed to determine inhibition of ethanol extract of soursop on acid production and adhesion of Streptococcus mutans.

\section{METHODS}

\section{Extraction}

The protocol experiment was approved by the Institutional Ethical Committee of the Faculty of Dentistry Gadjah Mada University Indonesia. Annona muricata leaves were extracted by maceration method, then the dried leaves were chopped into small pieces and extracted with $70 \%$ ethanol for $24 \mathrm{~h}$ at room temperature. The extracted solutions were filtered and evaporated in a rotary evaporator. The crude extracts were weighed and stored in refrigerator at $4^{\circ} \mathrm{C}$. Concentration of $150 \mathrm{mg} / \mathrm{ml} ; 125 \mathrm{mg} / \mathrm{ml} ; 100 \mathrm{mg} /$ $\mathrm{ml} ; 75 \mathrm{mg} / \mathrm{ml} ; 50 \mathrm{mg} / \mathrm{ml}$ extracts were dissolved with $5 \%$ dimethyl sulfoxide (DMSO). The extracts were stored in tiny containers and labeled accordingly. Chlorhexidine gluconate $(0.2 \%)$ was used as positive control due to its a broadspectrum antiseptic that is bactericidal while $5 \%$ DMSO as solvent for dissolving the extracts, was used as negative control.

\section{Acid production}

Bacterial strain used in this study was $S$. mutans (ATCC 25175). The bacterial suspension turbidity using $0.5 \mathrm{McF}$ arland standard that corresponded to approximately $\left(1.5 \times 10^{7} \mathrm{CFU} / \mathrm{ml}\right)$. To examine the effect of acid production by S. mutans, various concentrations of ethanol extract of Anona muricata leaf was added to $7 \mathrm{ml}$ of $\mathrm{S}$. mutans suspension in brain heart infusion (BHI) broth containing $1 \%$ sucrose. Two $\mathrm{ml}$ of the culture was scooped up during cultivation at $37^{\circ} \mathrm{C}$ and the $\mathrm{pH}$ was examined using a $\mathrm{pH}$ meter digital as described previously, with slight modification. ${ }^{15}$ Three replications were made for each group of experiment extracts.

Adhesion of S. mutans ATCC 25175 on S-HA discs Hydroxyapatite (HA) discs were prepared as described in previous study. ${ }^{14}$ Briefly, HA discs $(10 \times 2 \mathrm{~mm})$ were made by pressing HA bovine particles. To obtain solid HA then sintered for 120 min until $1300^{\circ} \mathrm{C}$ with the heating of $5^{\circ} \mathrm{C} /$ minute. Sterilised HA discs was store at the room temperature. The whole saliva were prepared as described in previous study. ${ }^{14}$

In the morning, unstimulated saliva was obtained from a healthy volunteer. Saliva was vortexed and centrifuged. Millipore filter membranes were used to purify the supernatant. The assay of bacterial adhesion was based on the technique described previously by Rahman et al. ${ }^{14}$ that was modified to simulate the effect of food consumption, S. mutans were grown at $37^{\circ} \mathrm{C}$ for 24 $\mathrm{h}$ in a tube containing $\mathrm{BHI}$ broth with $1 \%$ sucrose. The saliva-coated hydroxyapatite discs (S-HA discs) were immersed in bacterial suspension with various concentration of extract.

The positive control using chlorhexidine $0.2 \%$, and the negative control tube containing DMSO. The tubes were incubated for $24 \mathrm{~h}$ at $37^{\circ} \mathrm{C}$ to create the bacterial adherence. 
Saliva-coated hydroxyapatite discs were rinsed with KPB (Kalium Phosphate Buffer) and transferred into a new tube that contained KPB (pH 7.0). The adherent S. mutans adsorbed onto the S-HA discs were dispersed using a vortex for $60 \mathrm{sec}$ and the supernatant were spread on agar plate. The number of colonies were counted after $24 \mathrm{~h}$ of cultivation at $37^{\circ} \mathrm{C}$.

\section{Statistical Analysis}

The $\mathrm{pH}$ of the culture was measured using a digital $\mathrm{pH}$ meter, and the number of bacterial colonies was counted using a digital colony counter. The mean and standard deviation are presented as data. Statistical analyses were conducted using the one-way ANOVA test. Statistical significance was set at $p<0.05$.

\section{RESULTS}

Table 1. Effect of various concentrations of Annona muricata leaves extract on S. mutans acid production

\begin{tabular}{|c|c|c|c|c|c|}
\hline \multirow{2}{*}{ Concentration (mg/ml) } & \multicolumn{4}{|c|}{$\mathrm{pH}$ (incubation time/hours) } & \multirow{2}{*}{$\mathrm{p}$-value } \\
\hline & 0 & 4 & 8 & 24 & \\
\hline DMSO 5\% & $7.52 \pm 0.03$ & $7.52 \pm 0.04$ & $7.26 \pm 0.09$ & $5.26 \pm 0.47^{a}$ & - \\
\hline 50 & $6.50 \pm 0.03$ & $6.52 \pm 0.06$ & $6.60 \pm 0.06$ & $4.87 \pm 0.04^{*}$ & 1.00 \\
\hline 75 & $6.42 \pm 0.04$ & $6.49 \pm 0.04$ & $6.51 \pm 0.07$ & $5.25 \pm 0.09^{*}$ & 0.85 \\
\hline 100 & $6.24 \pm 0.07$ & $6.46 \pm 0.05$ & $6.54 \pm 0.06$ & $5.28 \pm 0.11^{*}$ & 0.13 \\
\hline 125 & $6.35 \pm 0.05$ & $6.23 \pm 0.01$ & $6.56 \pm 0.01$ & $5.31 \pm 0.03^{*}$ & 0.04 \\
\hline 150 & $6.22 \pm 0.04$ & $6.24 \pm 0.04$ & $6.44 \pm 0.07$ & $5.76 \pm 0.02^{*}$ & 0.02 \\
\hline Chx $0.2 \%$ & $7.17 \pm 0.03$ & $7.38 \pm 0.02$ & $7.33 \pm 0.06$ & $7.45 \pm 0.02^{*}$ & 0.01 \\
\hline
\end{tabular}

The mean and standard deviation are presented as a data $(\mathrm{pH})$

*Post-hoc test results compared with the negative control group after $24 \mathrm{~h}$ incubation

Annona muricata leaf extract reduced the rate of acid production by $\mathrm{S}$. mutans containing $1 \%$ sucrose (Table 1 ). As a result, there was a noticeable decrease in $\mathrm{pH}$ in the negative control group. However, the decrease was substantially repressed in the existence of the extracts (125-150 $\mathrm{mg} / \mathrm{ml}$ ) and significant compared to the negative control group after $24 \mathrm{~h}$ incubation $(\mathrm{p}<0.05)$. The decrease of $\mathrm{pH}$ was also inhibited in the positive control group.

The ability of the ethanol extract of Annona muricata leaf in inhibits the adhesion of S. mutans to the tooth surface was investigated using an in- vitro model by incorporating a hydroxyapatite discs. Adhesion decreased with increasing concentrations of ethanol extract of Annona muricata leaf.

Table 2 shows inhibition of adhesion by ethanol extract of Annona muricata leaf and manifested significant inhibition at concentrations $50-150 \mathrm{mg} / \mathrm{ml}$ compared with the negative control group $(p<0.05)$, also, the positive control group indicated an anti adherence activity. However, compared with the previous study ${ }^{14}$, the inhibition value in the present study at the concentration of $150 \mathrm{mg} / \mathrm{ml}$ was not suggested a similar value.

Table 2. Effect of various concentrations of Annona muricata leaves extract on S. mutans adherence to hydroxyapatite discs

\begin{tabular}{ccc}
\hline Concentration $(\mathrm{mg} / \mathrm{ml})$ & CFU/ml $\left(\times 10^{3}\right)$ & p-value \\
\hline DMSO $5 \%$ & $78,467 \pm 14,670^{\mathrm{a}}$ & - \\
50 & $4,593 \pm 1,474$ & 0.00 \\
75 & $3,480 \pm 1,911$ & 0.00 \\
100 & $2,090 \pm 306.43$ & 0.00 \\
125 & $1,677 \pm 94.52$ & 0.00 \\
150 & $770 \pm 60$ & 0.00 \\
Chx 0.2\% & 0 & 0.00 \\
\hline
\end{tabular}

aThe mean and standard deviation are presented as a data $(\mathrm{pH})$

*Post-hoc test results compared with the negative control group 


\section{DISCUSSION}

The application of natural products has been published to be one of the strategies for the development of new medicines. ${ }^{16} \mathrm{~S}$. mutans is usually recognized as one of the major roles in the accumulation of dental plaque and dental caries. ${ }^{2}$ The main virulence factors of Streptococcus mutans related to cariogenicity are adhesion, acidogenicity, and acid tolerance.

These three properties will be interrelated in changing the ecology of dental plaque. The ecological changes are marked by an increased proportion of Streptococcus mutans and other aciduric and acidogenic species. ${ }^{17}$ In the present study, we investigated the effect of ethanol extract of Annona muricata leaf on acid production and adhesion of S. mutans.

The acid production of the S. mutans are associated with dental caries. Demineralization on the tooth surfaces can occur due to the acid produced by the $S$. mutans during dietary sugar metabolism. ${ }^{16}$ In the present study, $1 \%$ sucrose was added at the culture medium to simulate the food diet.

Furthermore, sucrose among these sugars is investigated the most cariogenic carbohydrate in the human intake as it is a substrate for the unique capability to support the synthesis of polysaccharides (water-soluble or waterinsoluble) and acids by oral microorganisms, such as Streptococcus mutans. ${ }^{18}$ The alteration of $\mathrm{pH}$ is applied as an indicator to discover the influence of anticariogenic agents. ${ }^{15}$

As presented in Table 1, the ethanol extract of Annona muricata leaf at the concentration of 125 and $150 \mathrm{mg} / \mathrm{ml}$ significantly decreased the $\mathrm{pH}$ of S. mutans cells after 24 hours compared to the negative control $(p<0.05)$. The acidic $\mathrm{pH}$ rate reduction could be correlated with the intervention of agents to the bacterial glycolytic enzymes, which indicates specific intervention of the glycolytic activity of the bacterial cells rather than intervention by bacterial growth decrease. Furthermore, the interference of the bacterial cells' acid tolerance ability since the $\mathrm{pH}$ assay's final $\mathrm{pH}$ value shows acid tolerance. ${ }^{19}$

Adhesion of S. mutans to the superficial tooth structures is one of the most important steps for dental plaque formation. ${ }^{17}$ On the tooth surface, S. mutants will colonize after attachment using sucrose-dependent and sucroseindependent mechanicsm. ${ }^{20}$ The inhibitory effect of ethanol extract of Soursop leaf on the adhesion of S. mutans to S-HA discs was examined since the interference of the adhesion of S. mutans to the tooth surface is critical for the prevention of plaque accumulation. In the present study, the adhesion of $S$. mutans was examined using salivacoated hydroxyapatite discs (S-HA disc) and $\mathrm{BH}$ with $1 \%$ sucrose to simulate a sucrose-dependent mechanism. Ferrazano et al. ${ }^{16}$ said hydroxyapatite is a common surface to investigate the adherence of bacteria.

The glucosyltransferase enzyme produced by $S$. mutans plays an important role in the sucrosedependent mechanism. Glucosyltransferase influences the development of dental plaque and converts sucrose into glucan. This glucan will accommodate the possibility of providing both bacterial adhesions to the tooth surfaces and microorganisms to each other. ${ }^{20}$

The data demonstrated that various concentrations of ethanol extract of Annona muricata leaf reduced the adhesion of S. mutans on S-HA discs compared with the negative control group. Adhesion decreased with increasing concentrations of ethanol extract of Soursop leaf. At concentrations of $150 \mathrm{mg} / \mathrm{ml}$, the ethanol extract of Annona muricata leaf shows the lowest adherence colony of S. mutans to S-HA discs and significantly compared with negative control. Ethanol extract of Annona muricata leaf inhibits sucrose-dependent attachment by decreasing carbohydrate metabolism and sucrose-dependent production.

The reduction in adhesion was assumed to have a marked inhibitory effect on initial colonization and biofilm accumulation by $S$. mutans. But, this result was not completely inhibited at concentration $150 \mathrm{mg} / \mathrm{ml}$ compared with the previous study on independent-sucrose mechanism. ${ }^{14}$

This is possibly due to added $1 \%$ sucrose on $\mathrm{BHI}$ broth which may enhance cell survival under harsh conditions. However, these data imply that ethanol extract of Annona muricata leaf may be a novel substance capable of modulating the activity of dental caries-related factors. Further studies using in-vivo caries models are needed to explain 
and validate whether ethanol extract of Annona muricata leaf could be used as anticariogenic agents.

\section{CONCLUSION}

The ethanol extract of Annona muricata leaf can inhibit acid production and adhesion of S. mutans.

\section{ACKNOWLEDGMENT}

This work was supported by research grant from Faculty of Dentistry Gadjah Mada University, Indonesia

\section{REFERENCES}

1. Ministry of Health Republic Indonesia. Basic Health Survey. Jakarta; Department of Health Republic Indonesia; 2013.pp:110-9

2. Lemos JA, Palmer SR, Zeng L, Wen ZT, Kajfasz JK, Freires IA, Abranches J, Brady LJ. The Biology of Streptococcus mutans. Microbiol Spectrum. 2019; 7(1):1-18. DOI: 10.1128/ microbiolspec.GPP3-0051-2018

3. Yano A, Kikuchi S, Takahashi T, Kohama $K$, Yoshida Y. Inhibitory effects of the phenolic fraction from the pomace of Vitis coignetiae on biofilm formation by Streptococcus mutans. Arch Oral Biol 2012; 57(6): 711-9.DOI: 10.1016/j.archoralbio.2012.01.001

4. Samaranayake L. Essential Microbiology for Dentistry $4^{\text {th }}$ ed. Churchill Livingstone. 2012:279-282

5. Compean $\mathrm{KL}$ and Ynalvez RA. Antimicrobial activity of plant secondary metabolites: a review. Res J Med Plant. 2014; 8: 204-13.DOI: 10.3923/rjmp.2014.204.213

6. Lee M, Hwang YS. Anticaries Effect of Ethanol Extract of Terminalia chebula. Journal of Dental Hygiene Science. 2021;21(2):119-26. DOI: $10.17135 /$ jdhs.2021.21.2.119

7. Lee D-H, Seo B-R, Kim H-Y, Gum G-C, Yu H-H, You H-K, Kang TH, You Y-O. Inhibitory effect of aralia continentalis on the cariogenic properties of streptococcus mutans. J Ethnopharmacol. 2011;137: 979-84. DOI: 10.1016/j.jep.2011.07.015

8. Djais AA, Putri N, Jemmy, Putri AR, Darwita RR, Bachtiar BM. Effect of Propolis on Streptococcus mutans Biofilm Formation. Pesqui. Bras. Odontopediatria Clín. Integr. 2019; 19(e5221): 1-9.DOI: $10.4034 / \mathrm{PBOCl} .2019 .191 .138$

9. Hasan S, Danishuddin M, Khan AU. Inhibitory effect of zingiber officinale towards Streptococcus mutans virulence and caries development: in vitro and in vivo studies. BMC Microbiol. 2015; 15(1):1-14. DOI: $10.1186 /$ s12866-014-0320-5

10. Foong CP and Hamid RA. Evaluation of antiinflammatory activities of ethanolic extracts of annona muricata leaves. Rev Bras Farmacogn Braz J Pharmacogn. 2012;22(6):1301-7. DOI: 10.1590/S0102$\underline{695 \times 2012005000096}$

11. Abdulsalami MS, Aina VO, Ibrahim MB, Adejo GO, Audu G. Comparative Antibacterial Study of Aqueous and Ethanolic Leaf Extracts of Annona Muricata. J Natural Sci Res. 2016; 6(3): 141-6.

12. Pai BM, Rajesh G, Shenoy R, Rao A. Antimicrobial Efficacy of Soursop Leaf Extract (Annona muricata) on Oral Pathogens: An Invitro Study, J Clin Diagn Res. 2016; 10(11): ZC01-4. DOI: 10.7860/JCDR/2016/18329.8762

13. Rahman FA, Haniastuti T, Utami TW. Skrining fitokimia dan aktivitas antibakteri ekstrak etanol daun sirsak (Annona muricata L.) pada streptococcus mutans ATCC 35668. Maj Ked Gi Ind. 2017; 3(1): 1-7. DOI: 10.22146/ majkedgiind. 11325

14. Rahman FA, Haniastuti T, Utami TW. The effect of ethanol extract of soursop leaf (Annona muricata L.) on Adhesion of Streptococcus mutans ATCC 35668 to hydroxyapatite discs. Maj Ked Gi Ind. 2018; 4(1): 22-6. DOI: 10.22146/majkedgiind.24852

15. Kim BS, Park SJ, Kim MK, Kim YH, Lee SB, Lee KH, Choi NY, Lee YR, Lee YE, You YO. Inhibitory Effects of Chrysanthemum boreale Essential Oil on Biofilm Formation and Virulence Factor Expression of Streptococcus mutans. Evid Based Complement Alternat Med. 2015; 616309: 1-11. DOI: 10.1155/2015/616309

16. Ferrazzano GF, Amato I, Ingenito A, Zarrelly A, Pinto G, Pollio A. Plant Polyphenols and Their Anti-Cariogenic Properties: A Review. J. Mol. 2011; 16: 1486-507. DOI: 10.3390/ molecules 16021486

17. Alejandra BM, Daniel, OM. Virulence Factors 
of Streptococcus mutans Related to Dental Caries. In:Staphylococcus and Streptococcus. 2020:1-16. DOI: 10.5772 /intechopen.85807

18. Gupta P, Gupta N, Pawar AP, Birajdar SS, Natt AS, Singh HP. Role of sugar and sugar substitutes in dental caries: a review. ISRN Dent. 2013: 1-5. DOI: 10.1155/2013/519421

19. Ban SH, Kim JE, Pandit S, Jeon JG. Influences of Dryopteris crassirhizoma Extract on the
Viability, Growth and Virulence Properties of Streptococcus mutans. Molecules. 2012;17(8): 9231-44. DOI: 10.3390/molecules17089231

20. Krzyściak W, Jurczak A, Kościelniak D, Bystrowska B, Skalniak A. The virulence of Streptococcus mutans and the ability to form biofilms. Eur J Clin Microbiol Infect Dis. 2014; 33(4): 499-515. DOI: 10.1007/s10096-013$\underline{1993-7}$ 